\title{
Text Comprehension of Korean Developmental Dyslexic Children Considering Mode and Type of Texts
}

\author{
Joungmin Lee ${ }^{a}$, Woojeong Jang ${ }^{a}$, Hyoeun Won ${ }^{a}$, Soyeong Pae ${ }^{\mathrm{b}}$ \\ ${ }^{a}$ Department of Speech Pathology and Audiology, Graduate school Hallym University, Chuncheon, Korea \\ ${ }^{b}$ Division of Speech pathology and Audiology, Institute of Audiology \& Speech Pathology, Hallym University, Chuncheon, Korea
}

Correspondence: Soyeong Pae, $\mathrm{PhD}$ Division of Speech Pathology and Audiology, Institute of Audiology \& Speech Pathology, Hallym University, 1 Hallimdaehak-gil, Chuncheon 24252, Korea

Tel: +82-33-248-2214

Fax: +82-33-256-3420

E-mail: spae@hallym.ac.kr

Received: April 5, 2021

Revised: April 30, 2021

Accepted: April 30, 2021

This research was supported by Hallym University Research Fund (HRF-202001-006).
Objectives: Korean developmental dyslexic upper grade children's text comprehension abilities were investigated considering the mode of texts (reading vs listening) as well as the type of texts (narrative vs expository). Methods: Sixteen 5th to 6th graders with developmental dyslexia (DD) and grade and cognition-matched typically developing children (TD) participated in 4 text comprehension tasks. Each child responded to 32 questions, 8 in each text, tapping comprehension of texts counterbalancing the effect of mode and type of texts. Results: First, children with DD performed lower than TD children in text comprehension, reflecting developmental dyslexic Korean children's performance cross linguistically even with the high orthographic transparency of Hangeul. Second, children with DD performed better in the mode of reading compared to the mode of listening, which was the same as the TD children. Third, the effect of type of text was meaningful to only children with DD, while TD children's performance between narrative and expository text was not different. Conclusion: Korean upper grade children with DD seemed to rely heavily on the mode of reading in comprehending texts similarly to their grade-matched children, while children with DD had greater difficulties in comprehending the expository texts both in reading and listening modes compared to the narrative texts. Each child with DD's developmental level of the type and mode of texts needs to be considered to support his/her text comprehension abilities. Further studies need to be extended to the Korean language considering the type of texts with the DIER model.

Keywords: Korean developmental dyslexic children, Text comprehension, Mode and type of texts, Narrative text vs expository text 담화(discourse)는 언어를 사용할 때 두 문장 이상의 언어학적 단위를 의미하며(Paul \& Norbury, 2012), 의사소통 상황을 파악하 고 정보를 처리하여 상대방과 유연한 의사소통을 할 때 중요한 역 할을 한다(Ravid \& Tolchinsky, 2002). 성공적인 담화이해(discourse comprehension)를 위해서는 의미 및 구문 지식을 활용하여 듣거나 읽고 처리한 내용의 중심 내용을 파악하고 기억하여 자신의 의미, 구문 지식 등과 연결하여야 한다(Kamhi \& Catts, 2014). 또한 학년 이 올라감에 따라 일상적인 대화 수준의 담화뿐만 아니라, 서사적 구조, 설명, 설득과 같은 다양한 목적의 담화 정보를 이해하고 전달
하는 능력이 요구된다. 특히 교실환경에서의 담화이해는 개인과의 의사소통뿐만 아니라 학업성취를 위해서도 중요하다.

교실환경에서는 크게 듣기모드와 읽기모드를 통해 교과의 다양 한 내용을 학습하게 된다(McCray, Vaughn, \& Neal, 2001). 성공적 인 듣기모드에서의 담화이해를 위해서는 자신이 들은 정보를 기억 하고 배경지식을 바탕으로 폭넓게 해석하는 능력이 요구된다. 이에 더해 학년이 올라갈수록 문장간 연결능력, 담화 구조 지식을 필요 로 한다. 읽기모드에서의 담화이해를 위해서는 낱말, 문장, 담화 수 준의 언어능력을 통해 여러 문장을 연결하고 정보를 통합함으로써 
사고, 추론, 상상 및 해석을 포함하는 상위인지수준의 복잡한 처리 과정을 거친다(Cain \& Oakhill, 2007; Kamhi, 2007). 글에 담긴 내 용을 이해하고 요약, 정리하여 기억하는 읽기이해 능력은 학습의 중요한 역할을 하며, 읽기이해 능력의 증진은 학업성취와 직결된다 (Hwang \& Park, 2004).

Chall (1983)의 읽기발달 모델에 따르면 초등 고학년은 '읽기를 배우는 단계(learn to read)'에서 새로운 정보를 습득하는 '배우기 위해 읽는 단계(read to learn)'로 전환되는 시기이다. 읽기의 단순관 점 모델(Simple View of Reading, SVR)에서 성공적인 읽기이해를 위해서는 해독(decoding)과 언어이해(listening comprehension) 능력이 필요하며, 두 능력 중 하나라도 어려움이 있다면 성공적인 읽기이해가 이루어질 수 없다고 설명하고 있다(Gough \& Tunmer, 1986; Hoover \& Gough, 1990). 특히 초등 고학년이 되면 읽기가 자 동화되면서 초등 저학년보다 더 많은 인지적 자원을 읽기이해에 사 용하며, 어휘, 형태, 구문 등의 언어능력뿐만 아니라 담화수준의 언 어를 이해하는 능력을 통하여 읽기이해를 발전시킨다(Kim \& Pae, 2012; Kim, 2013; Yoon, 2015).

초등 저학년의 읽기이해와 듣기이해의 관계를 살펴본 Wolf, Muijselaar, Boonstra와 De Bree (2019) 연구에 의하면 읽기이해가 듣기이 해를 $34 \%$, 듣기이해가 읽기이해를 $40 \%$ 설명해준다고 하였다. 또한 영어권의 학생을 대상으로 일반 학생의 읽기이해를 설명하는 변인 을 연구한 선행연구에서도 낱말재인과 듣기이해가 읽기이해를 약 $72 ~ 85 \%$ 설명한다고 하였다(Hoover \& Gough, 1990). 또한 다수의 선행연구에서 읽기이해와 듣기이해가 서로 영향을 준다고 보고하고 있다(Cain, Oakhill, Barnes, \& Bryant, 2001; Lervåg, Hulme, \& Melby- Lervåg, 2017; Broek, 1994). 이는 담화이해를 살펴보기 위해서는 읽기이해 뿐만 아니라 듣기이해를 함께 살펴보는 것이 중요하다는 것을 시사한다. 영어권의 $2,4,6,8$ 학년 일반 학생 읽기이해와 듣기이 해를 비교한 선행연구에서는 초등 2 학년 학생은 읽기이해보다 듣기 이해 수행력이 높았으나, 학년이 올라갈수록 읽기이해와 듣기이해 의 수행력이 비슷해진다는 결과를 보고하였다(Diakidoy, Stlyianou, Karefillidou, \& Papageorgiou, 2005). 이 결과를 통하여 담화를 이해 할 때 초등 저학년 시기에는 듣기이해가 읽기이해를 지원해주는 반 면, 초등 고학년이 될수록 읽기이해와 듣기이해가 상호보완적으로 바뀐다는 것을 알 수 있다. 읽기이해가 초등 고학년까지 발달하며, 이에 대한 선행연구 결과는 초등 고학년의 읽기이해와 듣기이해 두 능력 간의 관계를 살펴보는 것이 중요하다는 것을 시사한다.

성공적인 교실담화 이해를 위해서는 교과과정 속의 제시되는 다 양한 글 유형을 이해하는 것이 중요하며, 특히 이야기담화와 설명 담화는 교실담화의 대표적인 담화유형이다(Kamhi \& Catts, 2014). 이야기(narrative)담화는 일반적으로 인과적인 사건의 연속이며 이 야기 문법을 갖추고 있다. 또한 개념, 아이디어 등이 시간적, 공간적 배열 안에 있으며 이 배열성이 학생들의 이해에 도움을 준다. 설명 (expository)담화는 설명, 순서, 비교/대조, 문제/해결, 주장과 같이 사실적 정보를 중시하며(Catts, Adlof, \& Weismer, 2006), 화제 지 향적이고 논리적 관계를 통해 연결된 개념과 아이디어가 나타난다 (Graesser, McNamara, \& Louwerse, 2003).

이야기담화와 설명담화에서 사용되는 담화 구조에 대한 지식은 담화를 이해하는 것에 영향을 준다(Cain, 1996, 2003; Cain \& Oakhill, 1996). 이야기담화의 구조는 기승전결이 있으며 앞부분의 내용 과 연결하여 일관된 맥락 속에서 내용을 이해하도록 돕는다(Broek, 1994; Zwaan, 1994). 한편 설명담화의 구조는 비교, 대조, 나열, 설 명 등 담화의 주제와 목적에 대한 이해가 필요하고, 학생의 배경지 식을 활용하여 해당 아이디어를 연결 짓는 것이 필요하다(Catin \& Oakhill, 2007; Rapp, Broek, McMaster, Kendeou, \& Espin, 2007; Broek, Lorch, Linderholm, \& Gustafson, 2001). 초등 4학년 학생의 글 유형에 따른 읽기이해 추론 특성을 살펴본 선행연구에서는 담 화유형에 따라 이해하기 위한 인지처리과정이 다르며, 이해를 위하 여 다른 이해 전략을 사용한다고 하였다(Kim \& Koh, 2019). 또한 초등학생을 대상으로 설명 글의 구조와 질문 유형에 따른 읽기이 해 능력을 살펴본 선행연구에서는 초등 고학년을 기점으로 설명 텍 스트가 발달하는 것으로 나타났다(Park \& Jung, 2018). 학년이 높 아질수록 학교에서 교사가 전달하는 정보의 대부분이 설명담화로 전달되기 때문에 교실환경에서 설명담화를 이해하는 것이 중요하 다. 이와 같은 선행연구의 결과는 학년이 올라감에 따라 이야기담 화 뿐만 아니라 설명담화에 대한 이해를 함께 살펴보는 것이 중요 함을 시사한다.

발달성 난독(developmental dyslexia) 학생은 듣기이해에 어려움 이 없음에도 불구하고 읽기이해는 또래보다 낮은 수행력을 가진 학 생들이다. 발달성 난독 학생은 정신질환 진단 및 통계 편람(American Psychiatric Association, 2013)에 의하면 지속적인 교육을 받았 음에도 불구하고 음운론적인 결함으로 인해서 정확하고 빠르고 유창한 낱말 해독을 하는 것에 어려움을 보이는 특정학습장애로 분류된다. 읽기의 단순관점 모델(Simple View of Reading, SVR)에 근거하였을 때 발달성 난독 학생은 언어 이해력은 좋으나 음운론 적 결함에 의하여 해독의 어려움을 겪는다고 보고되었다(Pae, Shin, \& Seol, 2017). 이러한 해독의 어려움은 초등 고학년까지 이어져(Kim \& Pae, 2012; Yoon, Kim, \& Pae, 2011), 글을 읽을 때 해독 및 읽기유 창성에 많은 에너지 자원을 사용하게 되어 읽기이해에 어려움이 발 생하게 된다(Catts, Fey, Tomblin, \& Zhang, 2002; Catts \& Hogan, 
2002; Kim \& Pae, 2013).

난독증 의심 증상을 보이는 한국 초등생 9 명을 대상으로 읽기관 련 변인과 진단 결과를 분석한 Lee와 Kim (2020)의 연구에 의하면, 발달성 난독증 학생은 읽고 이해하는 능력뿐만 아니라 듣기이해 능력을 함께 살펴보는 것이 중요하다고 한다. 듣기이해 능력은 음운 지각 및 기억을 포함한 음운처리능력을 필요로 하여 읽기능력과는 다른 처리능력이 요구된다. 이에 발달성 난독증 학생의 듣기이해 능 력 평가는 학생의 읽기특성을 정확하게 파악하는데 중요한 역할을 할수 있다고 제시하고 있다.

하지만 국내에서 발달성 난독 학생을 대상으로 한 담화이해 연 구는 드물다. 주로 학령기 담화이해에 대한 선행연구는 학습장애 로 분류되거나 읽기의 어려움만을 확인한 읽기장애를 대상으로 한 연구가 대부분이다(Kim \& Hwang, 2008; Kim, Yoo, Hwang, Kim, \& Koh, 2010). 특히 읽기와 듣기 두 가지 모드를 모두 살펴본 연구 는 매우 제한적이다(Jung, 2009; Kim \& Koh, 2019; Yoon, 2015). Lee, Won, Jang, Lee와 Pae (2020) 연구에서 초등 1학년 발달성 난 독 학생을 대상으로 듣기이해와, 낭독, 묵독 간의 차이를 살펴본 결 과, 듣기이해가 읽기이해에 비해 유의미하게 좋은 수행력을 보였으 나, 일반 학생보다 두 담화모드 모두에서 낮은 수행력을 보인 것으 로 나타났다. 이는 발달성 난독 학생 간의 개인차가 있다는 것과 함 께 읽기이해와 듣기이해를 동시에 살필 필요가 있다는 것을 시사한 다. 또한 학년이 올라감에 따라 담화유형이 다양해져 담화유형을 고려한 담화 이해력의 차이를 살펴볼 필요가 있다. 하지만 많은 담 화유형에 대한 연구에서는 단순언어장애, 읽기부진 학생과 같은 특정 장애 집단을 대상으로 한 연구가 대부분이며, 읽기모드 또는 듣기모드에서만 살펴보았다는 제한점이 있다(Kim \& Koh, 2019).

따라서 발달성 난독 학생의 담화모드 뿐만 아니라 담화유형을 고려한 담화이해 능력을 살피는 것이 필요하다. 발달성 난독 학생 과 일반 학생의 담화 이해력을 읽기모드 및 듣기모드와 이야기담화 및 설명담화를 고려하여 살펴보고자 한다.

\section{연구방법}

\section{연구대상}

본 연구는 서울, 경기도, 강원도 일반 초등학교 5-6학년에 재학 중인 발달성 난독 학생 16 명과 학년을 일치시킨 일반 학생 16 명을 대상으로 하였다(5학년 13명, 6학년 3명). 대상자 선정 기준은 다음 과같다.

발달성 난독 학생은 1) 한국 비언어성 지능검사 2판(K-CTONI-2; Park, 2014) 결과 지능지수 80 이상에 속하여 인지 영역에서 어려움
이 없으나, 2) 표준화된 검사인 한국어 읽기검사(KOLRA; Pae, Kim, Yoon, \& Jahng, 2015)에서 단어해독, 읽기유창성, 읽기이해를 포함 한 측정치 읽기지수 2 에서 표준점수 80 이하, 3) 한국어 핵심언어 임 상평가(K-CELF 5; Pae, Yoon, Seol, \& Jahng, in press) 하위검사 중 작문 쓰기 검사에서 표준편차 -1.5 이하로 나타나 읽기뿐만 아니라 작문능력에도 어려움을 보이는 학생으로 선정하였다. 읽기와 쓰기 면에서 어려움이 나타났으나 4) 한국어 읽기검사(KOLRA; Pae et al., 2015 ) 하위검사 중 듣기이해에서 표준점수 85 이상에 속하여 일상 적인 담화를 듣고 이해하는 것에 어려움이 없으며, 5) 한국어 핵심 언어 임상평가(K-CELF 5; Pae et al., in press)의 하위검사인 의미 범주 결과 표준편차 -1 이상에 속하여 어휘력에 제한이 없는 학생 으로 선정하였다. 또한 6) 부모나 담임교사로부터 대상자가 충분한 읽기 교육을 받았음에도 불구하고 읽기 및 쓰기 관련 학업을 힘들 어하였음이 보고된 학생으로 선정하였다.

일반 학생은 1) 한국 비언어성 지능검사 2판(K-CTONI-2; Park, 2014) 결과, 지능지수 80 이상에 속하여 인지 영역에서 어려움이 없 으며, 2) 한국어 읽기검사(KOLRA; Pae et al., 2015) 결과 읽기지수 2에서 표준점수 85 이상, 3) 한국어 핵심언어 임상평가(K-CELF 5; Pae et al., in press) 하위검사 중 작문 쓰기 검사에서 표준편차 - 1 초 과에 속하여 읽기와 작문 모두에서 어려움이 없는 학생으로 선정 하였다. 또한 3) 한국어 읽기검사(KOLRA; Pae et al., 2015) 하위검 사 중 듣기이해에서 표준점수 85 이상, 4) 한국어 핵심언어 임상평 가(K-CELF 5; Pae et al., in press)의 하위검사인 의미 범주 결과 표 준편차 - 1 이상에 속하여 일상적인 담화 듣기이해와 어휘력에 제한 이 없는 학생으로 선정하였다.

본 연구에서 선정된 발달성 난독 학생의 비언어성 지능지수 평균 100.00 (SD = 7.863), 한국어 읽기검사(Pae et al., 2015)의 읽기지수 2 평균 $43.2(\mathrm{SD}=28.125)$, 듣기이해 평균 $99.01(\mathrm{SD}=9.14)$ 로 나타 났다. 일반 학생은 비언어성 지능지수 평균 $109.8(\mathrm{SD}=17.775)$, 한국 어 읽기검사(Pae et al., 2015)의 읽기지수 2 평균 110.4 (SD=8.821), 듣기이해 평균 $106.8(\mathrm{SD}=7.43)$ 로 나타났다. 두 집단 간의 차이 검 증을 위하여 독립표본 $t$-test를 실시한 결과, 비언어성 지능지수 $(t=$ $-1.51, p>.05)$ 와 듣기이해 $(t=1.764, p>.05)$ 점수 사이에는 집단 간 유의한 차이가 나타나지 않았으나, 읽기능력을 살펴본 읽기지수 $2(t=-7.209, p<.001)$ 점수에서는 유의미한 차이가 나타났다.

\section{연구도구}

본 연구에서는 ‘한국어 해독해 3권: 이야기와 설명담화 독해(Jung, Jin, Kwag, Kim, \& Pae, 2017)의 이야기글 '병원입원'과 '식물키우 기', 설명글 ‘황사'와 ‘음식물 쓰레기를 줄이자’를 저자의 허락을 받 
아 연구자가 글과 질문유형을 수정 및 보완하여 사용하였다. 연구 에 사용한 글과 질문은 Appendix 1에 수록되어 있다. 검사에 사용 한 글은 '한국어 해독해 3권: 이야기와 설명담화 독해(Jung et al., 2017)'에 제시된 확장형 담화 글을 600 700자로 수정하여 사용하 였다. 각 담화는 문단 수를 3 개로 통일하였으며, 평균 문장 수 19 $(\mathrm{SD}=1.82)$, 평균 어절 수 $188.75(\mathrm{SD}=6.95)$, 평균 내용어 수 191.75 $(\mathrm{SD}=5.61)$, 평균 기능어 수 $153(\mathrm{SD}=7.61)$ 으로 수정 후 사용하였 다. 담화유형에 따른 질문은 사실적 이해, 추론적 이해 2 가지 유형 으로 구성하였으며, 질문 문항 수는 각 담화별로 사실적 이해 4 문 항, 추론적 이해 4 문항으로 총 8 문항씩 총 32 문항의 주관식으로 구 성하였다.

검사에 사용한 글과 질문은 문해 전문 언어재활사 4 명에게 타당 도를 검증받았다. 내용타당도 지수는 Likert 5 점 척도(매우 타당하 지 않다, 타당하지 않다, 보통이다, 타당하다, 매우 타당하다)로 실 시하였다. 담화에 대한 타당도는 평균 4.70점, 담화 질문에 대한 타 당도는 평균 4.32점으로 타당한 도구로 판단하였다.

\section{연구절차}

본 검사는 조용한 장소에서 개별 검사 형태로 학생과 검사자가 일대일로 실시하였다. 담화모드와 담화유형에 따른 순서 효과를 배제하기 위하여 검사 그룹을 4 가지 유형으로 나누어 실시하였다. 담화 이해력은 교실 상황을 반영하여 해당 질문지를 글로 제시하 고 답을 쓰도록 하였다.

읽기 검사 시, 학생에게 글을 제시하고 묵독으로 읽은 후 해당 질 문을 글로 제시한 다음 답을 쓰도록 하였다. 지문을 옆에 두도록 하 였으나, '글을 다시 봐도 된다’는 지침은 따로 주지 않았다. 듣기 검 사 시, 녹음한 파일을 들려주고 해당 질문을 글로 제시한 후 답을 쓰도록 유도하였다. 검사자는 글을 한 번만 들려줄 것이라고 안내 후 녹음 파일을 재생하였으며, 들을 때에는 글의 내용을 메모하지 못하도록 통제하였다.

담화이해를 측정하기 위한 질문지는 맞으면 1점, 틀리면 0 점으로 처리하여 텍스트마다 8 문항씩, 총 32 문항을 채점하였다. 채점 시 발 달성 난독 학생의 쓰기 특성을 고려하여 내용의 파악이 가능한 정 도의 철자법 오류는 맞는 것으로 채점하였다(예: '안된다' $\rightarrow$ '안됀 다, '숨쉬기' $\rightarrow$ ‘숨시기' 등). 담화이해 질문에 대한 채점 일치도를 측 정한 결과, 채점자 간 신뢰도는 $98.78 \%$ 로 나타났다.

\section{통계처리}

본 연구에서 수집된 자료를 SPSS 21.0 Windows용 프로그램을 사용하여 다음과 같이 분석하였다. 담화모드와 담화유형에 따른
집단 간의 차이가 있는지 살펴보기 위하여 집단(발달성 난독 학생, 일반 학생)과 담화모드(읽기, 듣기), 담화유형(이야기, 설명)을 각각 독립변수로, 담화이해 점수를 종속변수로 하여 삼요인 혼합분산분 석(Three-way Mixed-design ANOVA)을 실시하였다.

\section{연구결과}

\section{담화모드와 담화유형에 따른 집단 간의 담화 이해력 차이}

읽기 집단에 따른 담화모드와 담화유형에 따른 담화 이해력을 살펴본 기술통계 결과는 Table 1 과 같다.

읽기 집단, 담화모드 및 담화유형에 따라 담화 이해력에 차이가 있는지 분산분석을 실시한 결과, 첫째, 읽기 집단에 따라 주효과가 나타났다 $(F=40.934, p<.001)$. 발달성 난독 학생은 일반 학생에 비 해 담화 이해력이 낮게 나타났다. 둘째, 담화모드를 고려하여 읽기 집단의 차이를 살펴보았을 때, 읽기 집단과 담화모드 간에 상호작 용 효과가 관찰되지 않았다 $(F=1.901, p>.05)$. 그리고 담화모드의 주효과는 유의하게 나타났다 $(F=52.394 p<.001)$. 이는 발달성 난 독 및 일반 학생 모두 읽기에 비해서 듣기 수행력이 낮게 나타났음 을 알려준다. 셋째, 읽기 집단, 담화모드에 더해 담화유형을 고려하 여 담화 이해력을 살펴본 결과, 세 변인 간 상호작용 효과가 통계적 으로 유의미하게 나타났다 $(F=37.483, p<0.001)$. Figure 1에서 보 는 바와 같이 담화유형에서는 발달성 난독 학생은 읽기모드에서 이야기담화보다 설명담화에서 유의하게 낮은 수행력을 보였으며 $(t=8.125, p<0.001)$, 듣기모드에서도 담화유형 간의 유의한 차이 가 나타났다 $(t=5.000, p<0.001)$. 이와 대조적으로 Figure 2에서 보 는 것과 같이 일반 학생은 읽기모드에서 이야기담화와 설명담화 간 의 유의미한 차이가 나타나지 않았으며 $(t=0.495, p>.05)$, 듣기모드 에서도 담화유형 간의 유의미한 차이가 나타나지 않았다 $(t=1.074$, $p>$.05).

Table 1. Text comprehension of reading group's, discourse mode and discourse type

\begin{tabular}{lcc}
\hline & Dyslexia $(\mathrm{N}=16)$ & $\mathrm{TD}(\mathrm{N}=16)$ \\
\hline Reading & & \\
Narrative & $6.22(.975)$ & $6.63(1.500)$ \\
Expository & $4.81(.985)$ & $6.44(1.365)$ \\
Listening & & \\
Narrative & $5.03(1.596)$ & $4.94(1.181)$ \\
Expository & $3.78(1.518)$ & $4.44(1.632)$ \\
\hline
\end{tabular}

Values are presented as mean (SD).

Max score $=8$, Min score $=0$.

$\mathrm{TD}=$ Typically developing. 


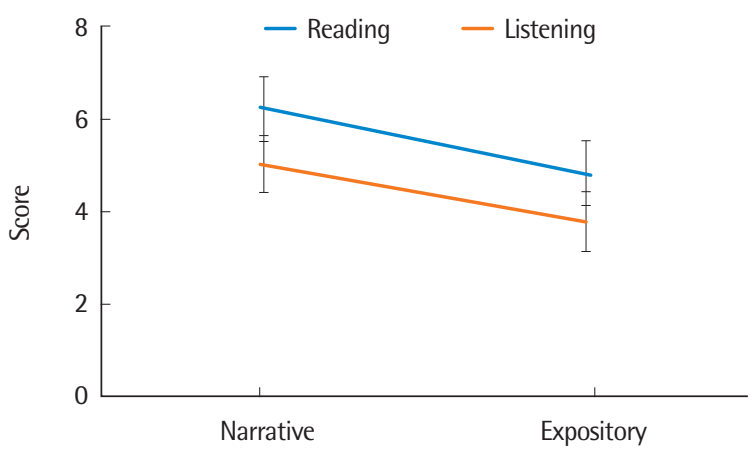

Figure 1. Text comprehension according to mode and type (dyslexia group).

\section{논의 및 결론}

본 연구는 담화모드(읽기, 듣기)와 담화유형(이야기, 설명)에 따 른 초등 고학년 발달성 난독 학생과 일반 학생의 담화 이해력의 차 이가 있는지 알아보았다. 연구 결과에 따른 논의는 다음과 같다.

발달성 난독 학생은 일반 학생보다 담화모드와 담화유형 모두에 서 낮은 수행력을 보였다. 이러한 결과는 발달성 난독을 대상으로 담화 이해력을 살펴본 다양한 언어권의 선행연구 결과와 일치하여 언어 보편적인 결과로 나타났다(Adlof \& Hogan, 2018; Conners \& Olson, 1990; Lauterbach, Park, \& Lombardino, 2017; Wong et al., 2017; Van Silfhout, Evers-Vermeul, \& Sanders, 2015). 국내 선행연 구를 살펴보면, 읽기에 어려움을 보이는 집단의 담화이해 능력을 살펴본 Woo (2012) 연구에서는 읽기이해 뿐만 아니라 듣기이해 영 역에서도 읽기장애 학생의 수행력이 일반 학생보다 낮은 수행력을 보였다는 결과와 유사하게 나타났다. 또한 읽기부진 학생 집단의 읽기이해 능력을 살펴본 선행연구와 비교하였을 때에도, 학년이 올 라갈수록 듣기이해에서도 어려움을 보인다는 결과와도 유사하다

(Cain \& Oakhill, 2007; Jung, 2009; Kim \& Pae, 2012).

이 결과는 Stanovich (2009)가 제안했던 읽기에 어려움을 보이는 학생들은 일반 학생보다 책을 덜 읽게 되고, 이로 인하여 어휘력 및 배경지식이 또래보다 낮아지면서 읽기능력 뿐만 아니라 언어능력 의 차가 갈수록 더 크게 된다는 마태효과(Mattew effect)의 영향인 것으로 추론할 수 있다. 또한 학년이 올라감에 따라 담화의 길이가 길어지고 구조가 복잡해짐에 따라 이야기담화를 이해하는 것에도 어려움을 보이게 되며, 상대적으로 배경지식을 요구하는 설명담화 역시 어려움이 나타나게 된다. 따라서 종단연구를 통하여 발달성 난독 학생의 담화 이해력이 담화모드 및 담화유형과 연관될 수 있 는지에 대해서 살펴볼 필요가 있다.

담화모드를 고려하여 담화 이해력을 살펴보았을 때, 발달성 난

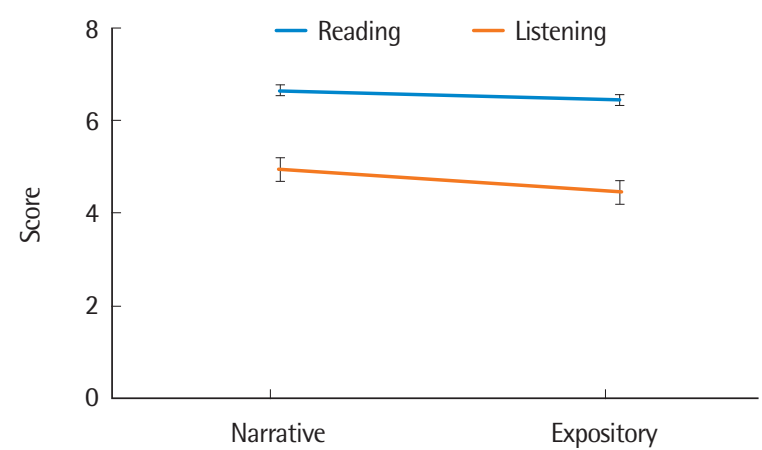

Figure 2. Text comprehension according to mode and type (TD group). $\mathrm{TD}=$ Typically developing.

독 학생은 일반 학생에 비해 유의미하게 낮은 담화 이해력을 보였 다. 초등 1 학년 발달성 난독 학생을 대상으로 듣기이해와 읽기이해 를 살펴본 Lee 등(2020)의 연구에서도 초등 1 학년 발달성 난독 학 생이 일반 학생보다 듣기모드와 읽기모드 모두에서 낮은 수행력을 보였는데 초등 고학년을 대상으로 한 본 연구에서도 같은 결과가 나타났다. 이는 고학년에 이르러서도 담화가 복잡해지면서 읽기이 해 뿐만 아니라 듣기이해에서도 어려움이 나타난 것으로 보이나, 종 단연구를 통해 발달경로를 추적할 필요가 있다.

또한 이 결과는 발달성 난독 학생도 고학년이 되면서 접하게 되 는 길고 복잡한 담화를 처리할 때 일반 학생처럼 음성언어 뿐 아니 라 문자언어에 많이 의존함을 시사한다. 읽기이해와 듣기이해의 관 계를 살펴본 선행연구 결과, 초등 저학년 시기에는 듣기이해가 읽기 이해를 지원해주지만, 초등 고학년이 될수록 읽기이해와 듣기이해 가 상호보완적으로 바뀐다고 나타났다(Kim \& Pilcher, 2016; Kim, 2016). 지적능력이 좋음에도 불구하고 발달성 난독 학생이 일반 학 생에 비해 읽기와 듣기 모두에서 낮은 수행력을 보였다는 결과는 읽기와 듣기 특성에 따른 맞춤형 지원이 필요함을 시사한다.

읽기 집단과 담화유형에 따른 담화 이해력을 살펴본 결과 상호 작용 효과가 나타났다. 발달성 난독 학생은 일반 학생보다 이야기 담화와 설명담화 모두에서 낮은 수행력을 보였다. 이는 일반 학생 은 이야기담화와 설명담화 간 담화이해 수행력 차이가 나지 않은 반면, 발달성 난독 학생은 이야기담화보다 설명담화에서 유의미하 게 낮은 수행력을 보인 것에 기인하였다. 즉, 담화를 이해하는데 있 어 일반 학생은 담화유형의 영향을 받지 않는 반면, 발달성 난독 학 생은 이야기담화보다 설명담화에서 어려움이 나타났다. 읽기이해 부진 학생과 일반 학생을 대상으로 설명글과 이야기글 읽기에서의 추론 특성을 분석한 Kim과 Koh (2019) 연구에서도 일반 학생은 글 의 유형에 영향을 받지 않는 반면, 읽기이해부진 학생은 이야기글 보다 설명글에서 수행력이 낮게 나타나 본 연구 결과와 유사하게 
나타났다.

또한 일반 학생을 대상으로 설명담화 이해를 주제로 한 Park과 Jung (2018) 연구에 의하면 설명글 읽기이해 발달은 중학년 이후에 이루어진다고 한다. 이는 일반 초등 고학년 학생은 이미 설명담화 이해가 중학년 시기에 발달하여 이야기뿐만 아니라 설명과 같이 다양한 담화를 이해하는 것에 어려움이 없음을 의미한다. 발달성 난독 학생은 설명담화 비중이 높은 고학년 교과 이해에 어려움을 겪을 수도 있다는 것을 의미하며, 이에 담화유형을 고려한 구체적 인 지원이 이루어져야 하며, 더 나아가 맞춤형 지원 효과에 대한 후 속연구가 필요하다.

결론적으로 이 연구는 담화모드, 담화유형을 함께 고려하여 집 단에 따른 담화 이해력의 수행력을 살펴보았다는 것에 의의가 있 다. 일반 학생은 담화모드가 담화 이해력에 영향을 끼치나 담화유 형에는 영향을 받지 않는 것으로 나타났다. 발달성 난독 학생은 담 화모드와 담화유형이 담화 이해력에 영향을 끼치는 것으로 나타났 다. 이는 발달성 난독 학생을 평가 및 중재할 때 담화모드와 담화유 형 모두를 고려해야 한다는 것을 시사한다.

본 연구는 발달성 난독 학생과 일반 학생의 담화모드와 담화유 형에 따른 담화 이해력의 차이를 봄으로써 발달성 난독 학생의 담 화 이해력의 특성과 담화 이해력 향상을 위한 평가 및 중재의 근거 를 마련하는데 기여하고자 하였다. 하지만 본 연구는 전체 학년이 아닌, 초등 5-6학년 만을 대상으로 하였다는 점에서 제한이 있다. 선행연구와 본 연구를 통하여 초등 저학년과 고학년 발달성 난독 의 특성을 보고하려고 하였으나, 대상자의 수가 적어 연구결과를 일반화하는 것에 주의가 필요하다. 따라서 많은 발달성 난독 학생 을 대상으로 초등 1학년에서 6학년 기간 동안의 담화 이해력 특성 의 변화를 살펴보는 종단연구가 필요하다. 또한 담화를 구성하는 텍스트의 양이 듣고 이해하는 것에 기억 부담이 있을 수 있어, 어절 수를 조절하는 것이 필요하다. 뿐만 아니라, Kim과 Koh (2019) 연 구에서 일반 학생은 글의 유형별로 다른 전략을 선택하여 담화를 이해하지만, 읽기부진 학생의 경우 전략을 선택하고 사용하는 것 에 한계가 있다고 한다. 이러한 선행연구의 결과를 바탕으로 담화 이해를 살펴보기 위한 질문을 세분화하고, 담화유형별 질문의 반 응을 분석하여 발달성 난독 학생의 특성을 세밀하게 살펴볼 필요 가 있다.

\section{REFERENCES}

Adlof, S. M., \& Hogan, T. P. (2018). Understanding dyslexia in the context of developmental language disorders. Language, Speech, and Hearing Services in Schools, 49(4), 762-773.

American Psychiatric Association. (2013). Diagnostic and statistical manual of mental disorder (5th ed.). Washington, DC: American Psychiatric Association.

Broek, P. V. D. (1994). Comprehension and memory of narrative text: inferences and coherence. In M. A. Gernsbacher (Ed.), Handbook of psycholinguistics (pp. 539-588). London, UK: Academic Press.

Broek, P. V. D., Lorch, R. F., Linderholm, T., \& Gustafson, M. (2001). The effects of readers' goals on inference generation and memory for texts. Memory \& Cognition, 29(8), 1081-1087.

Cain, K. (1996). Story knowledge and comprehension skill. In C. Cornoldi and J. Oakhill (Eds.), Reading comprehension difficulties: processes and remediation (pp. 167-192), Mahwah, NJ: Lawrence Erlbaum Associates.

Cain, K. (2003). Text comprehension and its relation to coherence and cohesion in children's fictional narratives. British Journal of Developmental Psychology, 21(3), 335-351.

Cain, K., \& Oakhill, J. (1996). The nature of the relationship between comprehension failure. Reading and Writing, 11, 489-503

Cain, K., \& Oakhill, J. (2007). Children's comprehension problems in oral and written language: a cognitive perspective. New York: Guilford.

Cain, K., Oakhill, J. V., Barnes, M. A., \& Bryant, P. E. (2001). Comprehension skill, inference making ability and their relation to knowledge. Memory and Cognition, 29(6), 850-859.

Catts, H. W., Adlof, S. M., \& Weismer, S. E. (2006). Language deficits in poor comprehenders: a case for the simple view of reading. Journal of Speech, Language, and Hearing Research, 49(2), 278-293.

Catts, H. W., Fey, M. E., Tomblin, J. B., \& Zhang, X. (2002). A longitudinal investigation of reading outcomes in children with language impairments. Journal of Speech, Language, and Hearing Research, 45(6), 1142-1157.

Catts, H. W., \& Hogan, T. P. (2002). The fourth grade slump: late emerging poor readers. Proceedings of the annual conference of the Society for the Scientific Study of Reading, 27-30.

Chall, J. S. (1983). Stages of reading development (2nd ed.). Fort worth, TX: Harcourt Brace.

Conners, F. A., \& Olson, R. K. (1990). Reading comprehension in dyslexic and normal readers: a component skills analysis. In D. A. Balota, G. B. F. d'Arcais, \& K. Rayner (Eds.), Comprehension processes in reading (pp. 557-579). Hillsdale, NJ: Erlbaum.

Diakidoy, I. N., Stlyianou, P., Karefillidou, C., \& Papageorgiou, P. (2005). The relationship between listening and reading comprehension of different 
types of text at increasing grade levels. Reading Psychology, 26(1), 55-80.

Gough, P. B., \& Tunmer, W. E. (1986). Decoding, reading and reading disability. Remedial and Special Education, 7(1), 6-10.

Graesser, A. C., McNamara, D. S., \& Louwerse, M. M. (2003). What do readers need to learn in order to process coherence relations in narrative and expository text. Rethinking Reading Comprehension, 82, 98.

Hoover, W. A., \& Gough, P. B. (1990). The simple view of reading. Reading and Writing, 2(2), 127-160.

Hwang, L. L., \& Park, H. S. (2004). The effect of story mapping strategy instruction on reading comprehension and listening comprehension of elementary students with reading disability. Korean Journal of Communication \& Disorders, 9(2), 156-170.

Jung, K., Jin, Y., Kwag, K., Kim, M., \& Pae, S. (2017). Korean decoding and reading comprehension with Korean cards: K-DRC. Seoul: Hakjisa.

Jung, M. (2009). Verbal analogical reasoning skills in poor comprehenders. Korean Journal of Communication \& Disorder, 14(3), 275-287.

Kamhi, A. G. (2007). Knowledge deficits: the true crisis in education. The ASHA Leader, 12(7), 28-29.

Kamhi, A. G., \& Catts, H. W. (2014). Language and reading disabilities: pearson new international edition. Harlow: Pearson.

Kim, A. H. (2013). Prediction of reading comprehension of elementary students: a 20-month longitudinal study. Communication Sciences \& Disorders, 18(3), 258-268.

Kim, A. H., \& Hwang, M. (2008). Prediction of reading skills in upper elementary students. Korean Journal of Communication \& Disorder, 13(1), 1-25.

Kim, A. H., Yoo, H. S., Hwang, M., Kim, U. J., \& Koh, S. R. (2010). Prediction of reading comprehension in elementary school students. Korean Journal of Communication \& Disorder, 15(3), 357-380.

Kim, M. B., \& Pae, S. Y. (2012). Reading skills and phonological processing abilities of Korean elementary school children with/without poor reading. Korean Journal of Communication \& Disorders, 17(4), 565-581.

Kim, M. B., \& Pae, S. Y. (2013). Listening and reading comprehension skills Korean elementary schoolchildren with reading difficulties. Communication Sciences \& Disorders, 18(4), 392-401.

Kim, W. R., \& Koh, H. J. (2019). The analysis of infernetial characteristics of poor comprehenders and average comprehenders on comprehension of expository text and narrative text: using "Think-aloud Method". The Journal of Korea Elementary Education, 30(2), 135-150.

Kim, Y. S. G., \& Pilcher, H. (2016). What is listening comprehension and what does it take to improve listening comprehension?. In R. Schiff \& M. Joshi (Eds.), Handbook of interventions in learning disabilities (pp. 159-173). Springer, Cham.

Kim, Y. S. (2016). Direct and mediated effects of language and cognitive skills on comprehension of oral narrative texts (listening comprehension) for children. Journal of Experimental Child Psychology, 141, 101-120.

Lauterbach, A. A., Park, Y., \& Lombardino, L. J. (2017). The roles of cognitive and language abilities in predicting decoding and reading comprehension: comparisons of dyslexia and specific language impairment. Annals of Dyslexia, 67(3), 201-218.

Lee, C. Y., Won, H., Jang, W., Lee, J., \& Pae, S. (2020). Text comprehension abilities of Korean 1st graders with and without developmental dyslexia in three access modes: listening, oral reading, and silent reading. Proceeding of 2020 conference of the Association for Reading and Writing in Asia.

Lee, E. J., \& Kim, Y. T. (2020). Identifying developmental dyslexia in 9 Korean elementary school students at risk for dyslexia. Communication Sciences \& Disorders, 25(3), 546-580.

Lervåg, A., Hulme, C., \& Melby-Lervåg, M. (2017). Unpicking the developmental relationship between oral language skills and reading comprehension: it's simple, but complex. Child Development, 89(5), 1821-1838.

McCray, A. D., Vaughn, S., \& Neal, L. V. I. (2001). Not all students learn to read by third grade: middle school students speak out about their reading disabilities. The Journal of Special Education, 35(1), 17-30.

Park, H. (2014). Korean version of comprehensive test of nonverbal intelligence second edition (K-CTONI-2). Seoul: Mindpress.

Park, M., \& Jung, K. H. (2018). Reading comprehension of expository texts in school-aged children according to text structure and question type. Communication Sciences \& Disorders, 23(1), 83-93.

Paul, R., \& Norbury, C. F. (2012). Language disorders from infancy through adolescence. St. Louis, MO: Elsevier Health Sciences.

Pae, S., Kim, M., Yoon, H., \& Jahng, S. (2015). Korean Languag based Reading Assessment (KOLRA). Seoul: Hakjisa.

Pae, S., Shin, G., \& Seol, A. (2017). Developmental characteristics of word decoding and text reading fluency among Korean children with developmental dyslexia. Communication Sciences \& Disorders, 22(2), 272-283.

Pae, S., Yoon, H. J., Seol, A., \& Jahng, S. (in press). Korean version of Clinical Evaluation of Languag fundementals 5 (K CELF 5), Seoul: Hakjisa.

Rapp, D. N., Broek, P. V. D., McMaster, K. L., Kendeou, P., \& Espin, C. A. (2007). Higher-order comprehension processes in struggling readers: a perspective for research and intervention. Scientific Studies of Reading, 11(4), 289- 
312.

Ravid, D., \& Tolchinsky, L. (2002). Developing linguistic literacy: a comprehensive model. Journal of Child Language, 29(2), 417-447.

Stanovich, K. E. (2009). Matthew effects in reading: Some consequences of individual differences in the acquisition of literacy. Journal of Education, 189(1-2), 23-55.

Van Silfhout, G., Evers-Vermeul, J., \& Sanders, T. (2015). Connectives as processing signals: how students benefit in processing narrative and expository texts. Discourse Processes, 52(1), 47-76.

Wolf, M. C., Muijselaar, M. M. L., Boonstra, A. M., \& De Bree, E. H. (2019). The relationship between reading and listening comprehension: shared and modality-specific components. Reading and Writing, 32(7), 1747-1767.

Wong, A. M. Y., Ho, C. S. H., Au, T. K. F., McBride, C., Ng, A. K. H., Yip, L. P. W., \& Lam, C. C. C. (2017). Reading comprehension, working memory and higher-level language skills in children with SLI and/or dyslexia. Read- ing and Writing, 30(2), 337-361.

Woo, J. H. (2012). A study of comparison of reading abilities characteristics between students with reading disabilities and general students and correlation of reading ability variables. The Journal of Special Education: Theory and Practice, 13(3), 291-312.

Yoon, H. J. (2015). Prediction of reading comprehension in early and late elementary grades: contribution of word decoding, vocabulary and syntactic knowledge. Communication Sciences \& Disorders, 20(4), 536-546.

Yoon, H. J., Kim, M., \& Pae, S. (2011). The decoding skills of school-aged children with poor reading skills. Korean Journal of Communication \& Disorders, 16(4), 582-596.

Zwaan, R. A. (1994). Effects of genre expectations on text comprehension. Journal of Experimental Psychology: Learning. Memory, and Cognition, 20 (4), 920-933. 
Appendix 1. 담화이해 과제

\begin{tabular}{|c|c|}
\hline 이야기담화 & 설명담화 \\
\hline 병원입원 & 황사 \\
\hline 오늘 아침에 나는 맛있게 밥을 먹었습니다. 그런데 갑자기 아랫배가 쑤시고 아 & 따뜻한 봄날이 되면 요즘에는 뿌옇게 찌푸린 하늘을 보는 날이 더 많아지고 있 \\
\hline 프기 시작했습니다. 그래서 나는 엄마에게 배가 아프다고 소화제를 달라고 했 & 습니다. 황사는 하늘이 누런 먼지로 덮이는 것입니다. 몽골이나 중국의 황토 \\
\hline 습니다. 엄마는 내게 소화제 한 알을 주셨습니다. 그런데 약을 먹었는데도 계 & 지대에서 발생한 모래 먼지가 하늘로 올라가서 떠다니다가 강한 바람에 의해 \\
\hline 속 배가 아팠습니다. 그래서 엄마와 함께 병원에 갔습니다. 응급실에 접수를 & 먼 곳까지 날아오는 것입니다. \\
\hline 하고 초음파 검사를 하였습니다. 검사 결과 의사 선생님께서는 배 아픈 이유 & 이러한 황사 현상으로 인해 어떤 문제가 발생할까요? 첫째, 미세먼지 때문에 숨 \\
\hline 가 충수에 염증이 생겼다고 하셨습니다. 그래서 충수를 잘라내는 맹장수술을 & 쉬기가 어려워 호흡기 질환이 생기거나 눈이나 피부 질환도 발생하기 쉽습니 \\
\hline 해야 한다며 입원하라고 하셨습니다. & 다. 둘째, 황사가 심해지면 미세먼지가 시야를 가려 외부 활동을 하기 어렵고, \\
\hline 나는 갑작스런 수술을 앞두고 너무 두려웠습니다. 엄마가 걱정하지 말고 한숨 & 비행기의 경우 이륙과 착륙할 때 위험하다고 합니다. 셋째, 황사 현상은 농작 \\
\hline 자고 오라고 손을 꼭 잡아주셨습니다. 길었던 맹장 수술이 끝났고 나는 잠에 & 물이나 활엽수의 성장에 방해가 되기도 합니다. 미세먼지가 햇빛을 가리고 나 \\
\hline 서 깨어났습니다. 엄마가 곁에서 밝은 얼굴로 웃고 계셨습니다. 그래서인지 & 뭇잎의 공기구멍을 막아 식물의 성장을 방해하기 때문입니다. 넷째, 작은 모 \\
\hline 이상하게도 수술한 곳은 아프지 않고 배가 너무 고팠습니다. 그래서 나는 밥 & 래나 먼지가 각종 정밀 기계류의 틈새에 끼면 고장의 원인이 됩니다. \\
\hline 을 먹고 싶다고 담당 간호사 선생님에게 말했습니다. & 이와 같은 황사의 피해에 대처하는 방법은 무엇이 있을까요? 우선, 황사가 발생 \\
\hline 간호사 선생님은 나에게 밥을 먹으려면 방귀를 꼭 뀌어야 한다고 하셨습니다. & 하게 되면 실내 공기를 깨끗하게 유지해야 합니다. 다음으로 호흡기가 약한 \\
\hline 왜냐면 수술하고 나서 정신은 깨어 있어도 마취의 약효가 남아서 장의 연동 & 사람이나 어린이, 노약자는 가능하면 외출을 자제하고, 외부 활동 시에는 반 \\
\hline 운동이 제대로 되지 않을 수 있다고 하셨습니다. 그래서 방귀가 나와야 장의 & 드시 마스크를 써야 합니다. 귀가한 후에는 손발을 깨끗이 씻어야 하며, 황사 \\
\hline 운동이 정상적으로 이루어진다는 신호라고 설명해주셨습니다. 나는 허기가 & 에 노출된 채소나 과일 등도 깨끗이 씻어서 먹어야 합니다. 황사의 피해의 근 \\
\hline 많이 졌는데 하루가 지나도 방귀는 계속 나오지 않았습니다. 나는 무엇보다 & 본적인 해결 방법은 무엇보다 중국의 황토지대에 나무를 심어 사막화를 막고, \\
\hline 된장찌개가 너무너무 먹고 싶었습니다. 그래서 병실 복도를 열심히 돌아다녔 & 방풍림을 조성하는 것입니다. 나무를 심으면 황사의 발생량을 줄 일뿐 아니라 \\
\hline 습니다. 그리고 순간 뿡 하는 소리와 함께 시원하게 방귀가 나왔습니다. 나는 & 모래 먼지가 날아올 때 방풍림이 이를 걸러 줄 수 있습니다. 이와같이 황사 현 \\
\hline 드디어 밥과 된장찌개를 먹을 수 있게 되어서 기뻤습니다. & 상에 잘 대처하여 건강한 삶을 누려야 합니다. \\
\hline 1. 나는 왜 소화제를 달라고 했나요? & 1. 황사는 어느 지역에서 발생하나요? \\
\hline 2. 나는 병원에 가서 왜 입원을 했나요? & 2. 황사로 인해 우리 몸에 해로운 것은 무엇인가요? \\
\hline 3. 나는 무슨 수술을 했나요? & 3. 황사로 인한 첫 번째 문제점은 무엇인가요? \\
\hline 4. 나는 수술 후에 배가 어떠했나요? & 4. 황사가 왜 농작물이나 활엽수의 성장에 방해가 될까요? \\
\hline 5. 밥을 먹고 싶다는 나에게 간호사는 뭐라고 말했나요? & 5. 황사 피해를 대처하기 위해 실내에서는 어떻게 해야 하나요? \\
\hline 6. 나는 밥을 먹기 위해 어떻게 했나요? & 6. 호흡기가 약한 사람이나 어린이, 노약자등은 어떻게 해야 한다고 했나요? \\
\hline 7. 나는 방귀를 뀌고 왜 기뻤나요? & 7. 왜 방풍림을 조성해야 하나요? \\
\hline 8. 만약 방귀가 나오지 않았다면 어떻게 해야 할까요? & 8. 이 글을 한 문장으로 요약해 보세요. \\
\hline
\end{tabular}




\section{국문초록}

\section{담화모드와 담화유형을 고려해서 본 초등 고학년 발달성 난독 학생의 담화 이해력 이정민 ${ }^{1}$ 장우정 ${ }^{1}$ 원효은 ${ }^{1}$ 배소영2 \\ '한림대학교 일반대학원 언어병리청각학과, ${ }^{2}$ 한림대학교 언어청각학부, 청각언어연구소}

배경 및 목적: 초등 고학년 발달성 난독 학생의 담화 이해력을 담화모드와 담화유형을 고려하여 살피고자 한다. 담화모드는 읽기모드 와 듣기모드로, 담화유형은 이야기담화와 설명담화를 중심으로 살펴본다. 방법: 초등 5-6학년인 발달성 난독 학생 16명과 학년일치 일 반 학생 16 명을 대상으로 담화 이해력을 측정하였다. 발달성 난독 학생은 이야기담화과 설명담화를 읽거나 듣고 총 32 개의 질문에 써서 답하도록 하였다. 각 담화는 3 문단으로 구성하였으며, 평균 문장 수는 19 개, 평균 어절 수는 188.75 개였다. 담화유형과 담화모드는 순서 효과가 배제되도록 진행하였다. 결과: 일반 학생 $(t=7.720, p<.001)$ 과 발달성 난독 학생 $(t=9.879, p<.001)$ 모두 읽기모드보다 듣기모드 에서 유의미하게 낮은 수행력을 보였다. 발달성 난독 학생은 이야기담화보다 설명담화에서 수행력이 듣기 $(t=5.000, p<.001)$ 와 읽기 $(t=8.125, p<.001)$ 모두에서 낮은 반면, 일반 학생은 담화유형에 따른 차이가 나타나지 않았다. 논의 및 결론: 이 연구는 담화모드, 담 화유형을 함께 고려하여 발달성 난독 학생의 담화 이해력을 살펴보았다는 것에 의의가 있다. 발달성 난독 학생은 담화모드와 담화유형 이 모두 담화 이해력에 영향을 끼치는 것으로 나타났다. 반면에 일반 학생은 담화모드가 담화 이해력에 영향을 끼치나 담화유형에는 영 향을 받지 않는 것으로 나타났다. 더 나아가 한국어에 DIER 모델의 글 유형을 고려한 확장된 연구가 필요하다.

핵심어: 발달성 난독증, 담화이해, 읽기 이해, 듣기이해, 이야기, 설명

본 연구는 한림대학교 연구비 지원(HRF-202001-006)에 의해 이루어짐.

\section{참고문헌}

김미배, 배소영 (2012). 초등 읽기부진 학생의 읽기특성. 언어청각장애연구, 17(4), 565-581.

김미배, 배소영 (2013). 학년에 따른 읽기부진 학생의 듣기 및 읽기이해능력.Communication Sciences \& Disorders, 18(4), 392-401.

김애화 (2013). 초등학생의 읽기이해 성취도에 대한 예측 변인 종단 연구: 20개월 간 추적 검사를 통하여. Communication Sciences \& Disorders, 8(3), 258-268.

김애화, 유현실, 황민아, 김의정, 고성룡 (2010). 초등학생의 읽기이해 능력 예측변인에 관한 연구. 언어청각장애연구, 15(3), 357-380.

김애화, 황민아 (2008). 초등학교 고학년의 읽기능력에 영향을 미치는 읽기관련변인에 관한 연구. 언어청각장애연구, 13(1), 1-25.

김우리, 고혜정(2019). 설명글과 이야기글 읽기에서 읽기이해부진 학생과 일반 학생의 추론 특성 분석: Think-aloud를 이용하여. 한국초등교육, 30(2), 135-150.

박민해, 정경희 (2018). 텍스트구조와 질문유형에 따른 학령기 학생의 설명글 읽기이해 특성. Communication Sciences \& Disorders, 23(1), 83-93. 박혜원 (2014). 한국 비언어 지능검사 2 (K-CTONI-2). 서울: 마인드프레스판.

박송이, 정경희(2018). 음독과 묵독에 따른 학령기 아동의 읽기유창성과 읽기이해 발달 특성. Communication Sciences \& Disorders, 23(4), 947-958. 배소영, 김미배, 윤효진, 장승민 (2015). 한국어 읽기 검사(KOLRA). 서울: 학지사.

배소영, 신가영, 설아영 (2017). 한국 발달성 난독 학생의 해독 및 읽기유창성 발달 특성. Communication Sciences \& Disorders, 22(2), 272-283. 배소영, 윤효진, 설아영, 장승민 (출판준비중). 한국어 핵심언어 임상평가(K-CELF). 서울: 학지사.

이은주, 김영태 (2020). 발달성 난독증 진단: 난독증 의심 증상을 보이는 한국 초등학생 9명을 대상으로. Communication Sciences \& Disorders, 25(3), 546-580.

우정한 (2012). 읽기장애학생과 일반학생의 읽기능력 특성 비교 및 읽기 하위 변인 간의 관계 연구. 특수교육저널: 이론과 실천, 13(3), 291-312. 윤효진 (2015). 초등 저학년과 고학년의 읽기이해 예측요인 연구. Communication Sciences \& Disorders, 20(4), 536-546. 
윤효진, 김미배, 배소영 (2011). 읽기부진학생의 해독 특성. 언어청각장애연구, 16(4), 582-596.

정경희, 진연선, 곽경미, 김미배, 배소영 (2017). 우리말 카드와 함께 하는 한국어 해독해. 서울: 학지사.

정미란 (2009). 초등학교 3-6학년 읽기이해 부진학생의 단어 유추. 언어청각장애연구, 14(3), 275-287.

황리리, 박현숙 (2004). 이야기 도식화 전략 교수가 초등 고학년 읽기장애 학생의 읽기 및 듣기 이해력에 미치는 효과. 언어청각장애연구, 9(2), 156-

170.

\section{ORCID}

이정민(제1저자, 대학원생 https://orcid.org/0000-0002-3870-5650); 장우정(공동저자, 대학원생 https://orcid.org/0000-0001-8023-2263); 원효은(공동저자, 대학원생 https://orcid.org/0000-0001-5782-3452); 배소영(교신저자, 교수 https://orcid.org/0000-0001-6577-0880) 